\title{
Interleukin-6 and Cyclooxygenase-2 downregulation by fatty-acid fractions of Ranunculus constantinopolitanus Sabreen F Fostok ${ }^{1,4}$, Rima A Ezzeddine ${ }^{2,4}$, Fadia R Homaidan ${ }^{3,4}$, Jamal A Al- Saghir ${ }^{3,4}$, Ralph G Salloum ${ }^{4,5}$, Najat A Saliba*2,4 and Rabih S Talhouk*1,4
}

Address: ${ }^{1}$ Department of Biology, Faculty of Arts and Sciences, American University of Beirut, Beirut, Lebanon, ${ }^{2}$ Department of Chemistry, Faculty of Arts and Sciences, American University of Beirut, Beirut, Lebanon, ${ }^{3}$ Department of Physiology, Faculty of Medicine, American University of Beirut, Beirut, Lebanon, ${ }^{4}$ Nature Conservation Center for Sustainable Futures (IBSAR), American University of Beirut, Beirut, Lebanon and ${ }^{5}$ Department of Internal Medicine/Pediatrics, School of Medicine, Wayne State University, Detroit, MI 48201, USA

Email: Sabreen F Fostok - sff07@aub.edu.lb; Rima A Ezzeddine - rae18@aub.edu.lb; Fadia R Homaidan - fh01@aub.edu.lb; Jamal A AlSaghir - jae13@aub.edu.lb; Ralph G Salloum - rsalloum@med.wayne.edu; Najat A Saliba* - ns30@aub.edu.lb;

Rabih S Talhouk* - rtalhouk@aub.edu.lb

* Corresponding authors

Published: 16 November 2009

BMC Complementary and Alternative Medicine 2009, 9:44 doi:I0.1 I86/1472-6882-9-44

This article is available from: http://www.biomedcentral.com/I472-6882/9/44

(c) 2009 Fostok et al; licensee BioMed Central Ltd.

This is an Open Access article distributed under the terms of the Creative Commons Attribution License (http://creativecommons.org/licenses/by/2.0), which permits unrestricted use, distribution, and reproduction in any medium, provided the original work is properly cited.
Received: 5 August 2009

Accepted: 16 November 2009

\begin{abstract}
Background: Medicinal plants represent alternative means for the treatment of several chronic diseases, including inflammation. The genus Ranunculus, a representative of the Ranunculaceae family, has been reported to possess anti-inflammatory, analgesic, antiviral, antibacterial, antiparasitic and antifungal activities, possibly due to the presence of anemonin and other. Different studies have shown the occurrence of unusual fatty acids (FAs) in Ranunculaceae; however, their therapeutic role has not been investigated. The purpose of this study is to characterize potential anti-inflammatory bioactivities in Ranunculus constantinopolitanus D'Urv., traditionally used in Eastern Mediterranean folk medicine.

Methods: The aerial part of $R$. constantinopolitanus was subjected to methanol $(\mathrm{MeOH})$ extraction and solvent fractionation. The bioactive fraction (I.2) was further fractionated using column chromatography, and the biologically active subfraction $\left(\mathrm{Y}_{2+3}\right)$ was identified using infrared (IR) spectroscopy, nuclear magnetic resonance (NMR) and gas chromatography-mass spectrometry (GC-MS). The effects of 1.2 and $Y_{2+3}$ on cell viability were studied in mouse mammary epithelial SCP2 cells using trypan blue exclusion method. To study the anti-inflammatory activities of 1.2 and $Y_{2+3}$, their ability to reduce interleukin (IL)-6 levels was assessed in endotoxin (ET)-stimulated SCP2 cells using enzyme-linked immunosorbent assay (ELISA). In addition, the ability of $Y_{2+3}$ to reduce cyclooxygenase (COX)-2 expression was studied in IL-I-treated mouse intestinal epithelial Mode-K cells via western blotting. Data were analyzed by one-way analysis of variance (ANOVA), Student-Newman-Keuls (SNK), Tukey HSD, two-sample t-test and Dunnett $t$-tests for multiple comparisons.
\end{abstract}

Results: The chloroform fraction (1.2) derived from crude $\mathrm{MeOH}$ extract of the plant, in addition to $\mathrm{Y}_{2+3}$, a FA mix isolated from this fraction and containing palmitic acid, $\mathrm{Cl} 8: 2$ and $\mathrm{Cl} 8: 1$ isomers and stearic acid (I:5:8:I ratio), reduced ET-induced IL-6 levels in SCP2 cells without affecting cell viability or morphology. When compared to fish oil, conjugated linoleic acid (CLA) and to individual 
FAs as palmitic, linoleic, oleic and stearic acid or to a mix of these FAs (I:5:8:I ratio), $\mathrm{Y}_{2+3}$ exhibited higher potency in reducing ET-induced IL-6 levels within a shorter period of time. $Y_{2+3}$ also reduced COX-2 expression in IL-I-treated Mode-K cells.

Conclusion: Our studies demonstrate the existence of potential anti-inflammatory bioactivities in $R$. constantinopolitanus and attribute them to a FA mix in this plant.

\section{Background}

Dietary supplements are used as preventive means to maintain a healthy state. Among them, polyunsaturated fatty acids (PUFAs), specifically members of the omega (n)-3 series and conjugated linoleic acid (CLA), have become the focus of extensive nutritional research in the last decade [1-6] due to their reported anti-inflammatory properties. Indeed, CLA and the $n-3$ eicosapentaenoic acid (EPA) and docosahexaenoic acid (DHA) were found to reduce the levels of many inflammatory mediators, including cytokines: interleukin (IL)-1, IL-6 and tumor necrosis factor (TNF)- $\alpha$, eicosanoids: prostaglandins (PGs), thromboxanes (TXs) and leukotrienes (LTs), enzymes: cyclooxygenase (COX)-2 and 5-lipoxygenase (LOX), adhesion molecules: E-selectin, intercellular adhesion molecule (ICAM)-1 and vascular cell adhesion molecule (VCAM)-1 and matrix metalloproteinases (MMPs) [7-10]. Clinically, reports have suggested that supplementation with $n$-3 fatty acids (FAs) has beneficial effects in chronic inflammatory diseases such as inflammatory bowel disease (IBD), rheumatoid arthritis (RA) and psoriasis [11]. Moreover, adding $n-3$ FAs to the diet of patients with hypertriglyceridemia is now recognized as an efficient triglyceride-lowering therapeutic measure [12]. CLA has been shown to possess similar effects, though the safety and efficacy of CLA dietary supplements is still under investigation $[9,13,14]$.

In contrast to the numerous reports investigating the protective effects of animal-derived PUFAs in inflammation, the literature describing anti-inflammatory bioactivities in plant-derived FAs, and particularly those existing in the Ranunculaceae family, used as a medicinal herb, is poor. This family, comprising around 2500 species distributed all over the world, is especially widespread in slow streams, ditches and shallow ponds of muddy mineralrich water. Ranunculus, a representative genus of the Ranunculaceae family, has been established as an antiinflammatory, analgesic, antiviral, antibacterial, antiparasitic and antifungal agent [15-20]. Such properties of this genus could be due to the presence of anemonin, a dimerization product of the $\gamma$-lactone protoanemonin, both of which have been shown to possess several pharmacological effects [18,21-23]. In this paper, the effect of a FA mix extracted from Ranunculus constantinopolitanus D'Urv., an Eastern Mediterranean plant that extends as far as Arme- nia, on endotoxin (ET)-induced IL-6 and IL-1-induced COX-2 in SCp2 and Mode-K cells, respectively, is investigated. This effect is subsequently compared to the activities of over-the-counter products reported to modulate inflammation, including fish oil and CLA.

\section{Methods \\ Cell culture}

Mouse mammary epithelial cell strain, SCp2 cells (kindly provided as a gift by P.Y. Desprez, Geraldine Brush Cancer Research Institute, California Pacific Medical Center, San Francisco, CA, USA) were cultured as previously described by Saliba et al. (2009) [24]. Briefly, cells were grown on 100-mm tissue culture plates (BD Falcon, Franklin Lakes, NJ, USA) in growth medium (GM) consisting of Dulbecco's Modified Eagle's Medium Nutrient Mixture/F12 Ham (DMEM/F12; Gibco, Paisley, Scotland) supplemented with 5\% heat-inactivated fetal bovine serum (FBS; Gibco), insulin ( $5 \mu \mathrm{g} / \mathrm{ml}$; Sigma, St. Louis, MO, USA) and $1 \%$ penicillin/streptomycin mixture (Gibco) in a humidified incubator $\left(95 \%\right.$ air $5 \% \mathrm{CO}_{2}$; VWR Scientific, West Chester, PA, USA) at $37^{\circ} \mathrm{C}$. Upon confluency, cells were detached by trypsinization and replated in GM either on 100-mm tissue culture plates for maintenance or on 6well plates (BD Falcon) at $1 \times 10^{6}$ cells/well to be used in different experiments. On the second day after plating, cells were shifted to differentiation medium (DM) consisting of DMEM/F12 supplemented with insulin (5 $\mu \mathrm{g} /$ $\mathrm{ml})$, hydrocortisone $(1 \mu \mathrm{g} / \mathrm{ml}$; Sigma), ovine prolactin (3 $\mu \mathrm{g} / \mathrm{ml}$; Sigma) and $1 \%$ penicillin/streptomycin. On the third day, unless otherwise indicated, plant and ET treatments were performed in triplicates.

Murine intestinal epithelial cell type Mode-K cells were cultured as previously described by Homaidan et al. (2003) [25]. Briefly, cells were maintained in DMEM containing $1 \mathrm{~g} / \mathrm{L}$ glucose and $10 \mathrm{mM}$ sodium pyruvate (Invitrogen, Carlsbad, CA, USA) and supplemented with $10 \%$ FBS (Invitrogen), 1\% non-essential amino acids (Invitrogen) and $0.5 \%$ penicillin/streptomycin (Invitrogen). At $70-80 \%$ confluency, cells were detached by trypsinization and replated on tissue culture flasks (BD Falcon) for maintenance or on 6 -well plates at $2 \times 10^{5}$ cells/well to be used in different experiments. On the second day after plating, cells were starved. Plant and IL-1 treatments were performed on the second and third days. 


\section{Extraction of plant material Collection and drying}

Ranunculus constantinopolitanus was collected from Yanta, Lebanon, located at an altitude of $1395 \mathrm{~m}$. A voucher specimen of the plant (voucher number: 72) was deposited at the Post Herbarium of the American University of Beirut, Beirut, Lebanon. Following collection, the aerial part (stems, leaves and flowers) of $R$. constantinopolitanus was dried by leaving the plant sample in the shade for two weeks before grinding it into approximately $10-\mathrm{mm}$ pieces using a blender. Ground samples were subjected to solvent extraction using methanol $(\mathrm{MeOH})$ or else they were stored at $-20^{\circ} \mathrm{C}$ for later use.

\section{Methanol extraction and fractionation}

The crude $\mathrm{MeOH}$ extract was subjected to further solvent fractionation as previously described by Saliba et al. (2009) [24]. In brief, the dried plant material was subjected to extraction through soaking in $\mathrm{MeOH}(1: 10 \mathrm{w} / \mathrm{v})$ for $16 \mathrm{hr}$. Incubation on a shaker at $20^{\circ} \mathrm{C}$ occurred in the first $2 \mathrm{hr}$, and then the plant sample was left in $\mathrm{MeOH}$ for the remaining time. The $\mathrm{MeOH}$ extract was filtered using a cheese cloth (sterile gauze sponges $30 \times 30 \mathrm{~cm}$ ) to give a solid phase (R-I) and a filtrate numbered "I" and referred to as "crude MeOH extract". R-I was soaked in ethyl acetate (EtOAc) at a ratio of 10:1 (w/v). It was then separated by filtration into a solid phase and a filtrate numbered "I.1". The crude MeOH extract (I) was evaporated to 1/10 of its volume at less than $40^{\circ} \mathrm{C}$, acidified to $\mathrm{pH} 2$ by concentrated $\mathrm{H}_{2} \mathrm{SO}_{4}$ and then separated into an aqueous and an organic layer using a mixture of $\mathrm{CHCl}_{3}$ and $\mathrm{H}_{2} \mathrm{O}(2: 1$ $\mathrm{v} / \mathrm{v}$ ). The organic layer was collected and labelled as "I.2". The aqueous layer was basified to $\mathrm{pH} 10$ by the addition of concentrated $\mathrm{NH}_{4} \mathrm{OH}$ and was then resuspended in a mixture of $\mathrm{CHCl}_{3}$ and $\mathrm{MeOH}(3: 1 \mathrm{v} / \mathrm{v})$ (the total volume of $\mathrm{CHCl}_{3}: \mathrm{MeOH}$ is equal to four times the volume of the aqueous layer) to be later separated into an organic layer and an aqueous layer labelled as "I.3" and "I.4", respectively. I.1, I.2, I.3 and I.4 were evaporated to dryness under vacuum, weighed, dissolved in $100 \%$ ethanol $(\mathrm{EtOH})$ and stored in dark bottles at $-20^{\circ} \mathrm{C}$. The fractions were subsequently screened for potential biological activities, and the active ones were selected for further purification.

Separation and identification of subfraction $Y_{2+3}$ Biologically active fraction I.2 ( $6 \mathrm{~g})$ was re-dissolved in a minimum volume of petroleum ether (P.ether): $\mathrm{CHCl}_{3}$ :EtOAc mixture $(2: 2: 1)$ and was applied to a column chromatography consisting of $800 \mathrm{~g}$ of silica gel. A gradient elution was performed using P.ether: $\mathrm{CHCl}_{3}$ :EtOAc $(2: 2: 1)(6500 \mathrm{ml})$, followed by P.ether: $\mathrm{CHCl}_{3}$ :EtOAc (1:3:1) (4000 ml), $\mathrm{CHCl}_{3}$ : EtOAc:MeOH (3:3:1) (4200 $\mathrm{ml})$ and $\mathrm{MeOH}$, successively. Subfraction $\mathrm{Y}_{2+3}$ was collected using P.ether: $\mathrm{CHCl}_{3}$ :EtOAc (2:2:1) as a mobile phase.
$\mathrm{Y}_{2+3}$, which had the highest biological activity, was purified via solid phase extraction (SPE). Spectroscopic data using infrared (IR) spectroscopy and nuclear magnetic resonance (NMR) showed that $\mathrm{Y}_{2+3}$ was a mixture of FAs. The mixture was consequently converted to FA methyl esters (FAMEs) and resolved into individual components using gas chromatography-mass spectrometry (GC-MS). GC analysis was performed using a Trace ${ }^{\mathrm{TM}}$ gas chromatograph equipped with HP-5 capillary column (30 m long, 250 $\mu \mathrm{m}$ i.d and $0.25 \mu \mathrm{m}$ film thickness), Helium as a carrier at a flow rate of $1 \mathrm{ml} / \mathrm{min}$. The maximum temperature was $350^{\circ} \mathrm{C}$. The column was heated from $35^{\circ} \mathrm{C}$ to $290^{\circ} \mathrm{C}$. The injector temperature was set at $300^{\circ} \mathrm{C}$ in a splitless mode. Results were recorded as percent of total peak areas. The mass spectrometer employed in the GC-MS analysis was a Polarization $\mathrm{Q}$ series mass selective detector in the electron impact (EI) ionization mode $(70 \mathrm{eV})$. Using appropriate reference standards of FAMEs, $\mathrm{Y}_{2+3}$ was identified as a mixture of four FAs: palmitic acid (C16:0), isomers of C18:2 and C18:1 and stearic acid (C18:0) in the corresponding proportion 1:5:8:1.

\section{Treatment of cells with plant extracts and fatty acids}

Plant extracts, fish oil, CLA, the FAs: palmitic, linoleic (cis9, cis-12-octadecadienoic acid), oleic (cis-9-octadecenoic acid) and stearic acid and a mix of the four FAs (1:5:8:1 ratio) were all diluted in $100 \% \mathrm{EtOH}$ and stored at $-20^{\circ} \mathrm{C}$. On day 3 after plating, SCp2 cells were treated with plant extracts or other FA compounds at different concentrations in DM supplemented with 1\% FBS up to a final volume of $1 \mathrm{ml} /$ well. Following treatment, cells were incubated at $37^{\circ} \mathrm{C}$ for different time points ( 24 or $48 \mathrm{hr}$ ) to assess cytotoxicity or for $30 \mathrm{~min}$ (short-term treatment) before ET treatment. For other experiments, media were supplemented with plant extracts or other FA compounds at different concentrations for 3 days as of the plating day (long-term treatment), and cells were treated with ET on day 3 .

For Mode-K cells, on day 2 after plating, cultures were pretreated with $\mathrm{Y}_{2+3}$ or a synthetic FA mix at different concentrations in the absence of FBS up to a final volume of $1 \mathrm{ml} /$ well. Following treatment, cells were incubated at $37^{\circ} \mathrm{C}$ for 8 or 12 hr before IL-1 treatment on day 3. Another method involved the cotreatment of Mode-K cells with $\mathrm{Y}_{2+3}$ or a synthetic FA mix and IL-1 on day 3 for $8 \mathrm{hr}$ under similar conditions.

\section{Induction of inflammation}

Endotoxin treatment of SCP2 cells

ET treatment was performed as previously described by Saliba et al. (2009) [24]. Salmonella typhosa ET (Sigma) was dissolved in DM, filter-sterilized using $0.2 \mu \mathrm{m}$ nonpyrogenic sterile- $\mathrm{R}$ filter and stored at $-20^{\circ} \mathrm{C}$. On day 3 after plating, cells were treated with ET at $10 \mu \mathrm{g} / \mathrm{ml}$ and then incubated at $37^{\circ} \mathrm{C}$ for $9 \mathrm{hr}$. 


\section{Interleukin-I treatment of Mode-K cells}

IL-1 treatment was performed as previously described by Homaidan et al. (2003) [25]. IL-1 $\alpha$ (US Biological, Swampscott, MA, USA) was dissolved in $1 \%$ bovine serum albumin (BSA; Invitrogen) and stored at $-20^{\circ} \mathrm{C}$. On day 3 after plating, cells were treated with IL- 1 at $10 \mathrm{ng} / \mathrm{ml}$ and then incubated at $37^{\circ} \mathrm{C}$ for 6 or $8 \mathrm{hr}$.

\section{Trypan blue exclusion method}

Twenty-four or $48 \mathrm{hr}$ post plant treatment, viable and dead SCp2 cells were counted using the trypan blue exclusion method. It involves the trypsinization of the attached cells and washing them using the same treatment medium, which contains dead cells, to form a suspension of the total treated cells. An aliquot of $50 \mu \mathrm{l}$ is taken from this suspension and mixed with an equal volume of trypan blue (Gibco). Dead cells stain blue, while viable cells appear bright. The percentage of viability is calculated relative to the control.

\section{Enzyme-linked immunosorbent assay (ELISA)}

\section{Sample collection}

Media of SCp2 cells were sampled from triplicate wells 9 hr post ET treatment. Forty $\mu$ l of complete protease inhibitors [one tablet dissolved in $2 \mathrm{ml}$ of double distilled water (DDW); Roche Diagnostics GmbH, Mannheim, Germany] was added to each $1 \mathrm{ml}$ of sample. Samples were stored at $-80^{\circ} \mathrm{C}$ until the day of the assay.

\section{Interleukin-6 assay}

A two-site (sandwich) ELISA was performed for the quantitative determination of mouse IL-6 (mIL-6) present in SCp2 cell culture media, using mIL-6 ELISA immunoassay kit (BioSource International, Inc., Camarillo, CA, USA). The IL-6 assay was performed according to manufacturers' instructions. All standards and samples were run in duplicates on high-binding 96-well microtiter plates (Thermo Labsystems, Philadelphia, PA, USA). The optical density was measured at a wavelength of $450 \mathrm{~nm}$ by an ELISA microplate reader (Multiskan Ascent, Thermo Labsystems). Concentrations were calculated using the Ascent software and were expressed in $\mathrm{pg} / \mathrm{ml}$.

\section{Western blotting}

Mode-K cells were washed twice with phosphate-buffered saline (PBS) and scraped in $2 \times$ electrophoresis sample buffer (SB) containing 0.25 M Tris-HCl (pH 6.8; Amersham Biosciences, San Diego, CA, USA), 4\% w/v sodium dodecyl sulfate (SDS; Amersham Biosciences), 20\% w/w glycerol (Amersham Biosciences), 0.1\% bromophenol blue and $40 \mu \mathrm{l} / \mathrm{ml}$ protease inhibitor cocktail (Biomol, Plymouth Meeting, PA, USA). Samples were then collected in microfuge tubes, boiled for $5 \mathrm{~min}$, centrifuged and the supernatant representing total soluble protein extract was collected and stored at $-80^{\circ} \mathrm{C}$.
Total protein extracts were run on a $12 \%$ SDS-polyacrylamide gel (BioRad, Hercules, CA, USA), and the gels were transferred to polyvinylidene difluoride (PVDF) membranes (Amersham Biosciences) overnight at $4^{\circ} \mathrm{C}$. Following transfer, membranes were washed once with TPBS wash buffer (PBS containing 0.1\% Tween 20) and then blocked in 5\% non-fat dry milk for $2 \mathrm{hr}$ at room temperature. Rabbit polyclonal COX-2 antibody (Cayman Chemical, Ann Arbor, MI, USA) was then added to the membranes and incubated for $2 \mathrm{hr}$ at room temperature. Unbound antibodies were washed three times with TPBS. Horse-raddish peroxidase (HRP)-conjugated anti-rabbit IgG (Santa Cruz Biotechnology, Santa Cruz, CA, USA) was added at 1:5000 dilution for $1 \mathrm{hr}$ at room temperature. Membranes were washed, incubated with luminol reagents (Santa Cruz Biotechnology) and directly exposed to autoradiography.

\section{Statistical analysis}

Data were expressed as mean \pm S.D. The effectiveness of plant treatments was analyzed by one-way analysis of variance (ANOVA). To check for treatments with similar effects, Student-Newman-Keuls (SNK) and Tukey HSD tests were performed. The effect of each treatment, if any, was then compared to the control using two-sample t-test or Dunnett t-tests for multiple comparisons. All statistical analyses were carried out using statistical program for social sciences (SPSS) 11.5, except for t-test, which was performed using Excel. Statistical probability of $P<0.05$ was considered significant.

\section{Results}

Effect of R. constantinopolitanus extracts on endotoxininduced interleukin-6 levels in SCp2 cells

Ranunculus constantinopolitanus (Figure 1), known for its folk medicinal value, was subjected to chemical extraction and purification. The crude $\mathrm{MeOH}$ extract (I) from this plant was cytotoxic to SCp2 cells. Accordingly, I.2, the chloroform fraction derived from that extract, was tested for its biological activity on SCp2 cells. To determine the maximum concentration of I.2 that can be used without affecting cell viability or morphology, SCp2 cells were treated with I.2 at different concentrations $(10,25,50$ or $100 \mu \mathrm{g} / \mathrm{ml}$ ) or EtOH, as a vehicle control, and viable cell counts were determined. None of the tested concentrations affected cell morphology $24 \mathrm{hr}$ post-treatment (Data not shown), and cell viability for all concentrations did not vary significantly from the control treatment (Figure 2A). Thus, the ability of I.2 to inhibit ET-induced IL-6 was studied to evaluate its potential anti-inflammatory activities. SCp2 cells pretreated with I.2 at the different concentrations $(10,25,50$ or $100 \mu \mathrm{g} / \mathrm{ml})$ showed, in a concentration-dependent manner, a significant reduction in IL-6 levels stimulated by ET (Figure 2B). Basal IL-6 levels were noted in cells pretreated with $100 \mu \mathrm{g} / \mathrm{ml}$. 

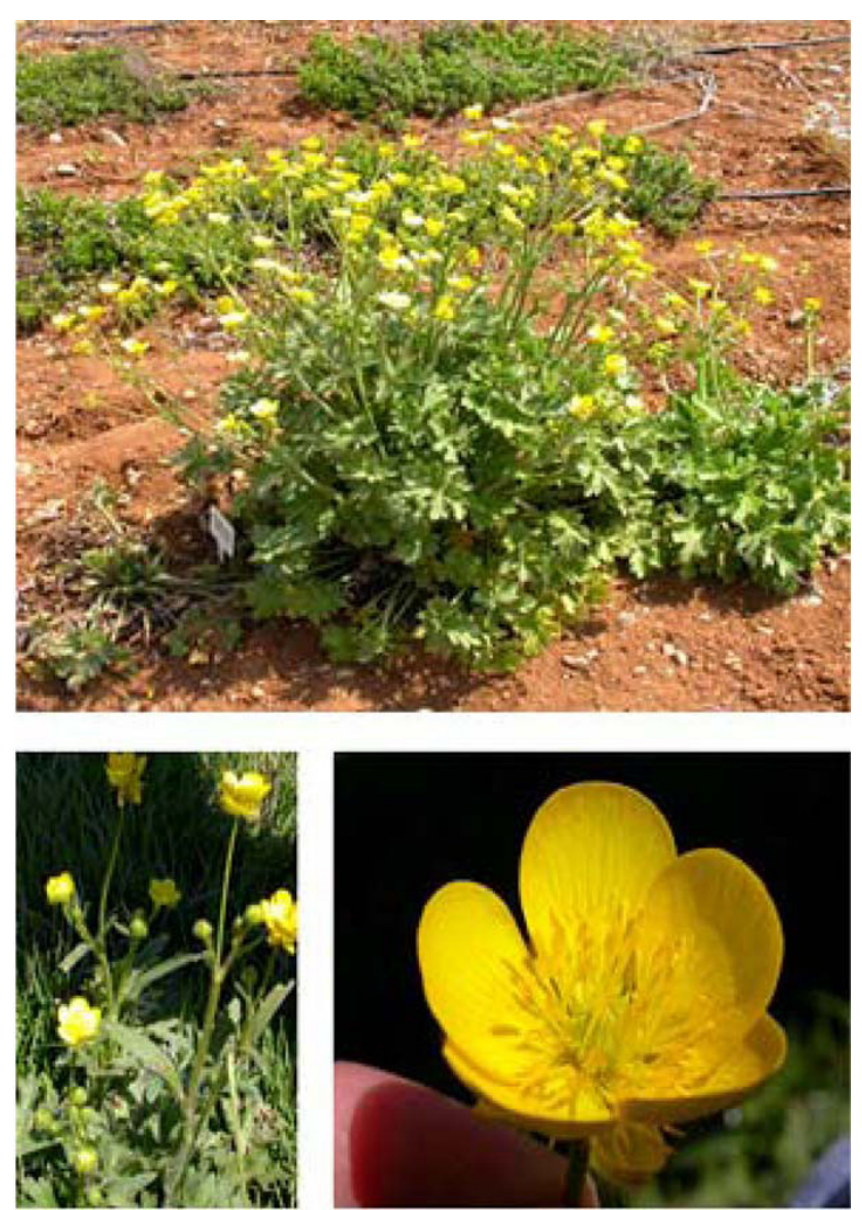

Figure I

Ranunculus constantinopolitanus. Ranunculus constantinopolitanus (Arabic name: Hawdhan fa'ri) is an Eastern Mediterranean plant that grows in Aintab and extends from Hasbayya to Jazzin. Description: "Villous below, appressed-hairy above. Root-fibers descending directly from neck. Root-leaves triangular-ovate, ternate, with obovate, cut, and coarsely toothed lobes. Carpels large, ovate, striate, smooth, ending abruptly in a very short, hooked beak". Its flowering season falls between April and June [4I]. The plant has been identified by Dr. Nada Sinno-Saoud, and a voucher specimen (voucher number: 72) was deposited at the Post Herbarium of the American University of Beirut, Beirut, Lebanon. Photos courtesy of Mr. Khaled Sleem (2004), Crop Production and Protection Department, Faculty of Agricultural and Food Sciences, American University of Beirut, Beirut, Lebanon.

Treatment of SCp2 cells with $\mathrm{Y}_{2+3}$ at different concentrations $(10,20$ or $30 \mu \mathrm{g} / \mathrm{ml})$ or EtOH, as a vehicle control, did not alter cell morphology at any of the tested concentrations for up to $48 \mathrm{hr}$ post-treatment (Data not shown). In addition, cell counts performed at the same time point showed that cell viability for each concentration was similar to that of the control treatment (Figure 3A). Consequently, $\mathrm{Y}_{2+3}$ was used at concentrations not exceeding 30 $\mu \mathrm{g} / \mathrm{ml}$ in all subsequent experiments.
To check if the anti-inflammatory effect previously observed with I. 2 was due to the $\mathrm{Y}_{2+3}$ subfraction, the ability of the latter to inhibit ET-induced IL- 6 was evaluated. SCp2 cells were pretreated with different $\mathrm{Y}_{2+3}$ concentrations, not exceeding $30 \mu \mathrm{g} / \mathrm{ml}$, using two modes of treatment. Short-term treatment at $5,10,15$ or $20 \mu \mathrm{g} / \mathrm{ml}$ resulted in a concentration-dependent downregulation of ET-induced IL-6 levels (Figure 3B). This reduction was significant at all the tested concentrations and exceeded 50\% inhibition at the highest $\mathrm{Y}_{2+3}$ concentration $(20 \mu \mathrm{g} / \mathrm{ml})$. Long-term treatment at $5 \mu \mathrm{g} / \mathrm{ml}$ significantly downregulated ET-induced IL-6 levels by more than 50\% (Figure 3C).

Potency of $Y_{2+3}$ versus its presumed fatty acid components, fish oil or conjugated linoleic acid in regulating endotoxininduced interleukin-6 levels in SCP2 cells

The effect of $\mathrm{Y}_{2+3}$ in inhibiting ET-induced IL- 6 was compared to that of short- or long-term treatment with each of the individual FA constituents, i.e. palmitic and stearic acid and the two most common C18:2 and C18:1 isomers: linoleic (cis-9, cis-12-octadecadienoic acid) and oleic (cis-9-octadecenoic acid) acid, respectively, at concentrations similar to those previously used with $\mathrm{Y}_{2+3}$. It was noted that $\mathrm{Y}_{2+3}$ significantly reduced ET-induced IL- 6 levels upon both short- and long-term treatment of SCp2 cells (Figure 4A and 4B). However, none of the individual FAs could reduce IL- 6 levels at concentrations ranging from $5-20 \mu \mathrm{g} / \mathrm{ml}$ following short-term treatment (Figure $4 \mathrm{~A}$ ) or at a concentration of $5 \mu \mathrm{g} / \mathrm{ml}$ following long-term treatment (Figure 4B). Furthermore, neither short-term treatment at $5-20 \mu \mathrm{g} / \mathrm{ml}$, nor long-term treatment at $5 \mu \mathrm{g} /$ $\mathrm{ml}$ with a synthetic mix of palmitic, linoleic (cis-9, cis-12octadecadienoic acid), oleic (cis-9-octadecenoic acid) and stearic acid in the same proportion as in $\mathrm{Y}_{2+3}$ could reduce ET-induced IL-6 levels (Figure 4A and 4B). In fact, in both modes of treatment the mix induced higher levels of IL- 6 than those induced by ET alone, similarly for linoleate in short-term treatment and stearate and palmitate in longterm treatment. Noteworthy is that linoleate was cytotoxic to cells in long-term treatment mode.

n-3 FAs and CLA are notoriously associated with antiinflammatory properties and are available in many forms as over-the-counter supplements. The ability of fish oil, containing the $n-3$ FAs EPA and DHA (1:0.76 ratio), to reduce ET-induced IL- 6 levels was compared to that noted with $\mathrm{Y}_{2+3}$. SCp2 cells were exposed to short- or long-term treatment with fish oil at concentrations similar to those used with $\mathrm{Y}_{2+3}$. In contrast to $\mathrm{Y}_{2+3}$, short-term fish oil treatment did not reduce IL-6 levels induced by ET, but rather enhanced such levels by at least $40 \%$ (Figure 5A). However, long-term treatment significantly reduced IL-6 to approximately $25 \%$ of the control levels (Figure 5B). Worth mentioning is the fact that fish oil reduced IL-6 lev- 
A

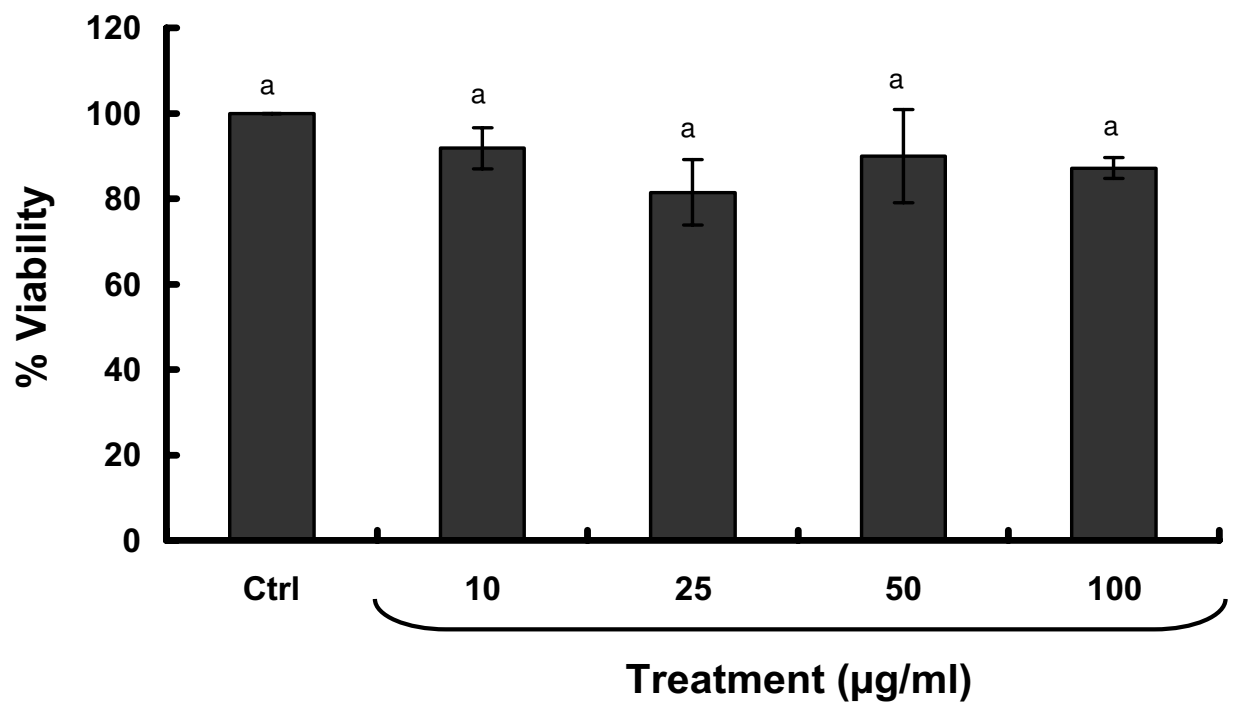

B

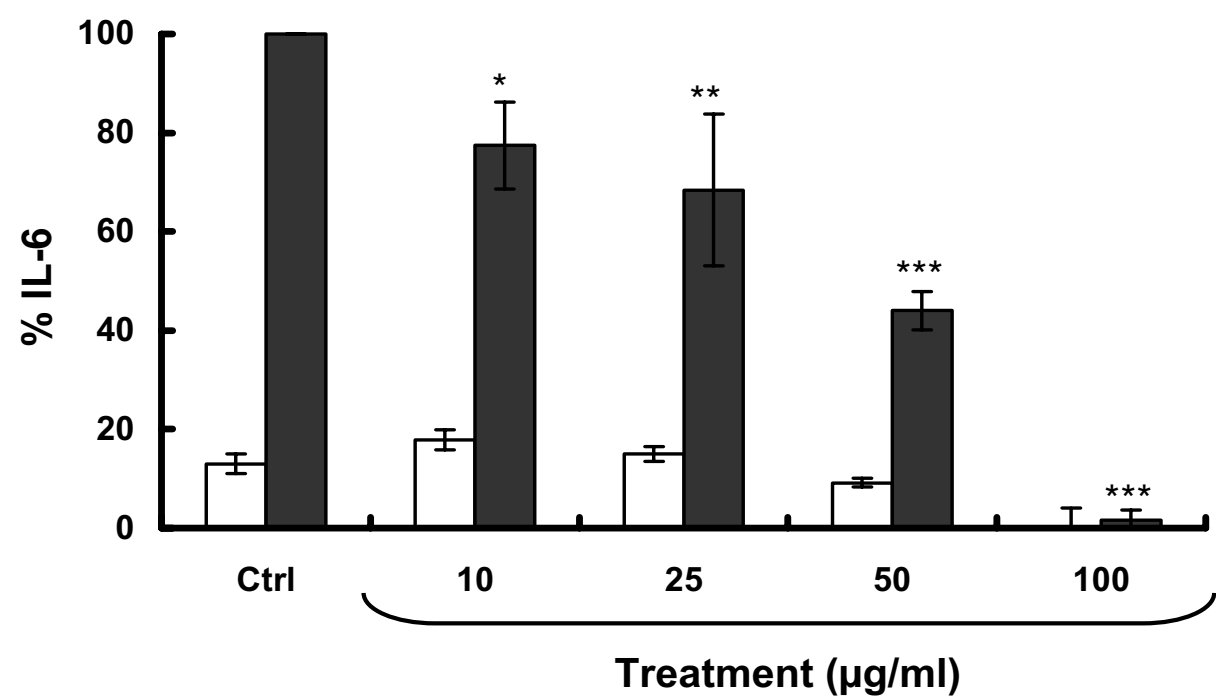

Figure 2

Exposure of SCp2 cells to $R$. constantinopolitanus fraction 1.2 at noncytotoxic concentrations reduces, in a concentration-dependent manner, ET-induced IL-6 levels. SCp2 cells were treated on day 3 of culture with EtOH (Ctrl) or 1.2 at different concentrations in DM supplemented with I\% FBS: (A) Twenty-four hr later, trypan blue assay was performed. (B) Thirty min later, cells were treated with ET at $10 \mu \mathrm{g} / \mathrm{ml}$ and their media collected $9 \mathrm{hr}$ post-ET. The values depicted are the means ( \pm S.D.) of a triplicate treatment. Means with the same letter are not significantly different. Statistical significance of the difference from Ctrl+ET is with $* P<0.05$, $* * P<0.01$ or $* * * P<0.00$ I. (Ctrl, control; ET, endotoxin; IL-6, interleukin-6). -ET (white square); +ET (black square). 
els more than $\mathrm{Y}_{2+3}$ at similar concentrations upon longterm treatment.

The ability of short- or long-term CLA treatment to reduce ET-induced IL-6 levels in SCp2 cells was also compared to that of $\mathrm{Y}_{2+3}$. At noncytotoxic concentrations $(0.1,0.5,1$ and $3 \mu \mathrm{g} / \mathrm{ml}$ ), short-term CLA treatment did not reduce IL6 levels, except for a marginal, but significant, reduction at $3 \mu \mathrm{g} / \mathrm{ml}$ (Figure 5C). This reduction was less than that observed with $\mathrm{Y}_{2+3}$ at $10 \mu \mathrm{g} / \mathrm{ml}$. Following long-term treatment, CLA $(0.1,0.5$ or $1 \mu \mathrm{g} / \mathrm{ml})$ significantly reduced IL-6 levels more so than that noted for $\mathrm{Y}_{2+3}$ at the 0.5 and $1 \mu \mathrm{g} /$ $\mathrm{ml}$ level (Figure 5D). Concentrations of CLA at 3 and $5 \mu \mathrm{g} /$ $\mathrm{ml}$ were cytotoxic to cells upon long- and short-term treatment, respectively.

\section{Effect of $Y_{2+3}$ on interleukin-I-induced cyclooxygenase-2 expression in Mode-K cells}

The effect of $\mathrm{Y}_{2+3}$ on COX-2 protein levels in Mode-K cells was assessed by pretreating the cells with $\mathrm{Y}_{2+3}$ at $10 \mu \mathrm{g} / \mathrm{ml}$ for 8 or $12 \mathrm{hr}$ prior to 6 -hr treatment with $10 \mathrm{ng} / \mathrm{ml}$ of IL1 or cotreating cells with $\mathrm{Y}_{2+3}$ and IL- 1 for $8 \mathrm{hr}$. $\mathrm{Y}_{2+3}$ caused a significant decrease in IL-1-induced COX-2 levels at 12hr pretreatment as well as 8-hr cotreatment with IL-1 (Figure 6A). As with SCp2 cells, the effect of the synthetic mixture of FA components of $\mathrm{Y}_{2+3}$ on COX-2 protein levels in IL-1-treated Mode-K cells was tested. At $10 \mu \mathrm{g} / \mathrm{ml}$, a similar concentration to $\mathrm{Y}_{2+3}$, the synthetic mix did not reverse the IL-1-induced COX-2 levels in Mode-K cells (Figure 6B, left panel). The synthetic mix failed to reverse these levels even at a higher concentration of $60 \mu \mathrm{g} / \mathrm{ml}$ (Figure 6B, right panel).

\section{Discussion}

In this study, we report the existence of anti-inflammatory activities in $R$. constantinopolitanus (Arabic name: Hawdhan fa'ri), commonly used in Eastern Mediterranean folk medicine, using in-vitro models of inflammation. Previous work in our laboratory established an in-vitro model of inflammation [26]. In this model, treatment of mouse

A

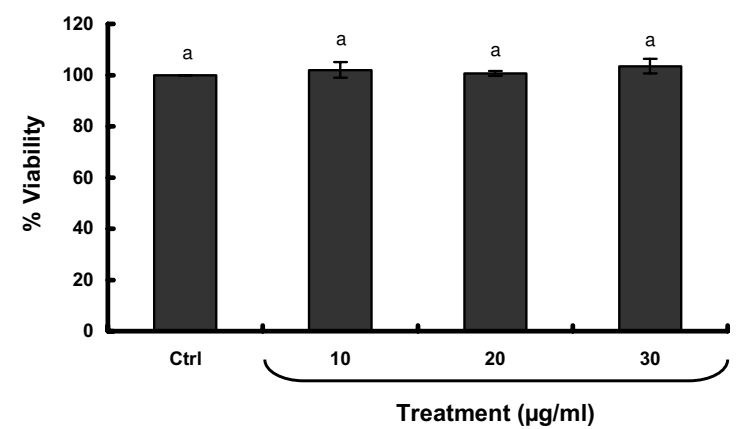

B

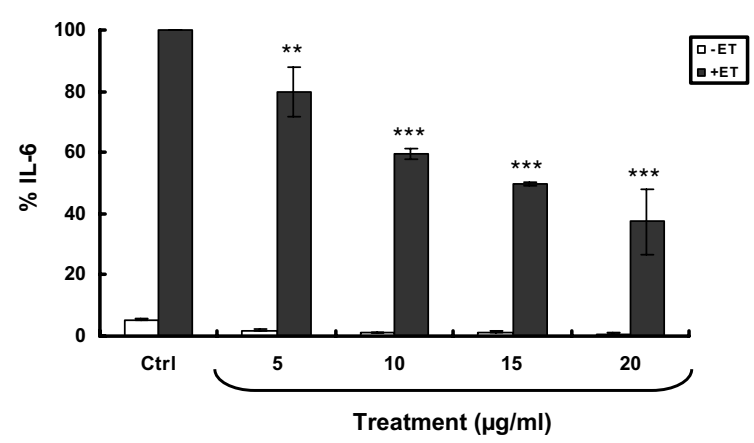

$\mathrm{C}$

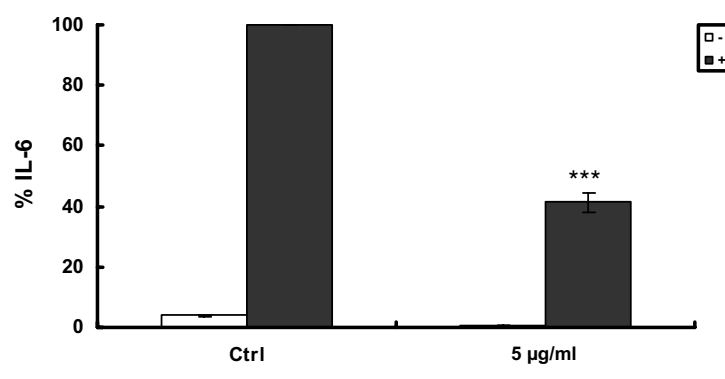

Figure 3

Exposure of SCp2 cells to $Y_{2+3}$ at noncytotoxic concentrations reduces, in a concentration-dependent manner, ET-induced IL-6 levels. (A) SCp2 cells were treated on day 3 of culture with EtOH (Ctrl) or $\mathrm{Y}_{2+3}$ at different concentrations in DM supplemented with I\% FBS. Forty-eight hr later, trypan blue assay was performed. SCp2 cells were treated (B) on day 3 of culture 30 min before ET (short-term exposure) or (C) for 3 days (long-term exposure), as of day I of culture, with $\mathrm{EtOH}(\mathrm{Ctrl})$ or $\mathrm{Y}_{2+3}$ at different concentrations. Cells were treated on day 3 with ET at $10 \mu \mathrm{g} / \mathrm{ml}$ in DM supplemented with $1 \%$ FBS and their media collected $9 \mathrm{hr}$ post-ET. The values depicted are the means $( \pm$ S.D.) of a triplicate treatment. Means with the same letter are not significantly different. Statistical significance of the difference from Ctrl+ET is with **P $<0.01$ or $* * * P<$ 0.00I. (Ctrl, control; ET, endotoxin; IL-6, interleukin-6). -ET (white square); +ET (black square). 
A

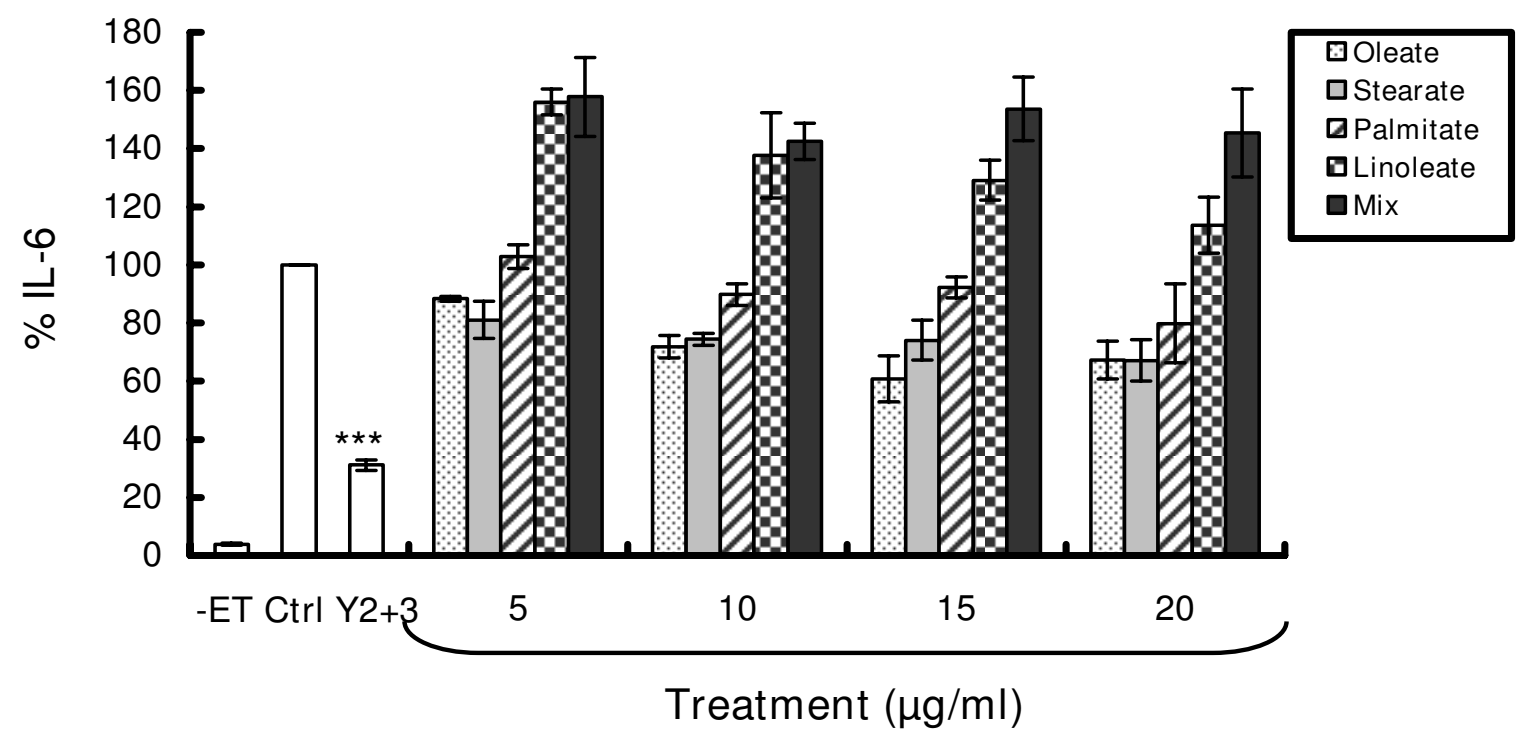

B

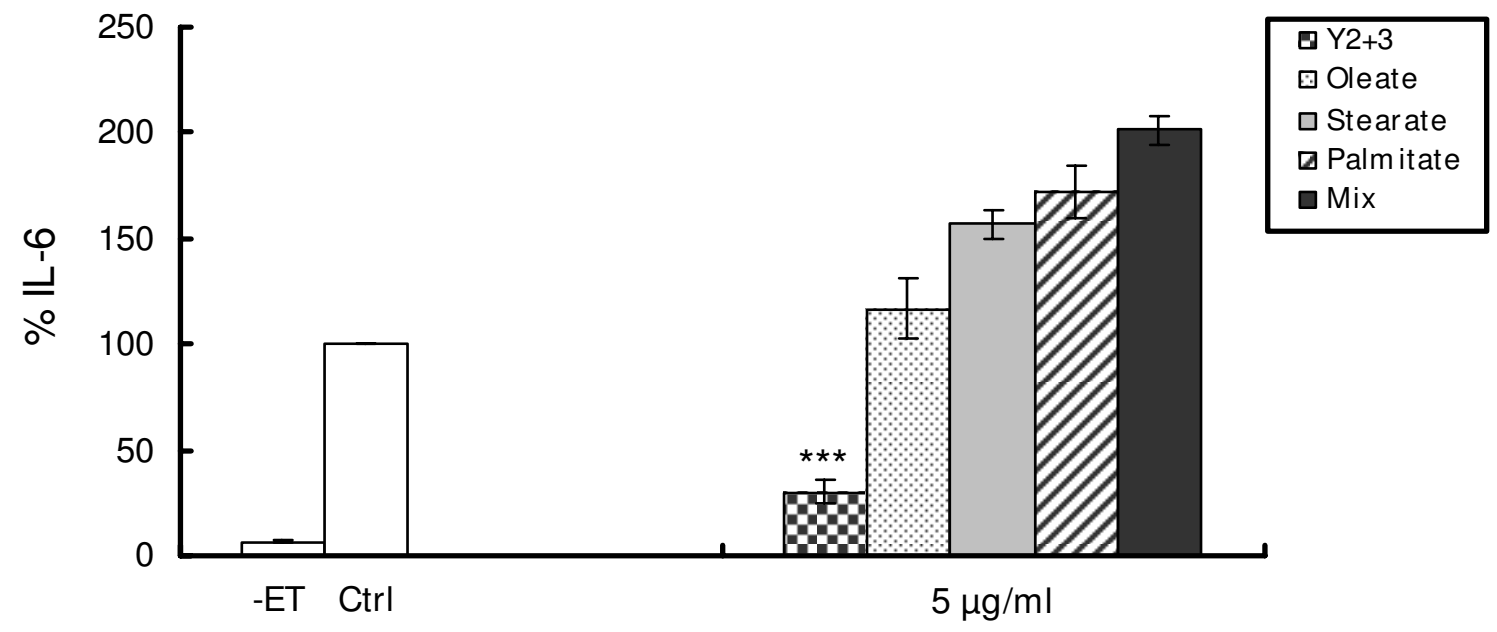

\section{Figure 4}

Exposure of SCp2 cells to individual FA components of $\mathbf{Y}_{2+3}$ or a synthetic FA mix does not reduce ET-induced IL-6 levels. SCp2 cells were treated (A) on day 3 of culture 30 min before ET (short-term exposure) or (B) for 3 days (longterm exposure), as of day I of culture, with $\mathrm{EtOH}(\mathrm{Ctrl}), \mathrm{Y}_{2+3}{ }^{\mathrm{a}}$, palmitate, linoleate ${ }^{\mathrm{b}}$, oleate, stearate or a synthetic FA mix at different concentrations. Cells were treated on day 3 with ET at $10 \mu \mathrm{g} / \mathrm{ml}$ in DM supplemented with I\% FBS and their media collected $9 \mathrm{hr}$ post-ET. The values depicted are the means ( \pm S.D.) of a triplicate treatment. Statistical significance of the differ-

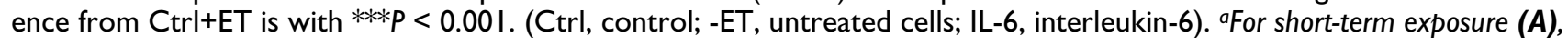
cells were treated with $Y_{2+3}$ at $10 \mu \mathrm{g} / \mathrm{ml}$. b Long-term exposure (B) to linoleate at $5 \mu \mathrm{g} / \mathrm{ml}$ was cytotoxic to cells. 
mammary cells with ET at $10 \mu \mathrm{g} / \mathrm{ml}$, a noncytotoxic concentration, enhanced nuclear factor (NF)- $\kappa \mathrm{B}$ DNA-binding activity, suppressed $\beta$-casein expression and upregulated pro-inflammatory mediators, including gelatinases (MMP-2 and MMP-9) and cytokines (IL-6 and TNF- $\alpha$ ). Consequently, SCp2 mouse mammary epithelial cell strain was utilized to assess potential in-vitro antiinflammatory activities in $R$. constantinopolitanus. In reviewing the literature, we highlighted the role phenols, flavonoids and terpenoids play in treating inflammation [27]. Accordingly, I.2, the chloroform fraction derived from the crude $\mathrm{MeOH}$ extract of the plant and presumably rich in these compounds, was assessed for its anti-inflammatory effects in ET-treated SCp2 cells. Due to its importance in the transition from the acute to the chronic phase of inflammation [28], IL-6 has been chosen as an inflammation marker to be monitored in our study. I.2 significantly reduced ET-induced IL- 6 levels without altering cell viability or morphology. From there, I. 2 was further fractionated and purified to yield a FA mix, $\mathrm{Y}_{2+3}$. Short- and

A

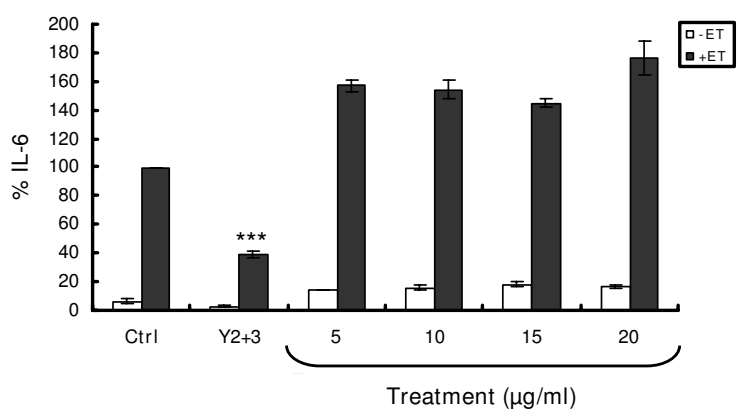

C

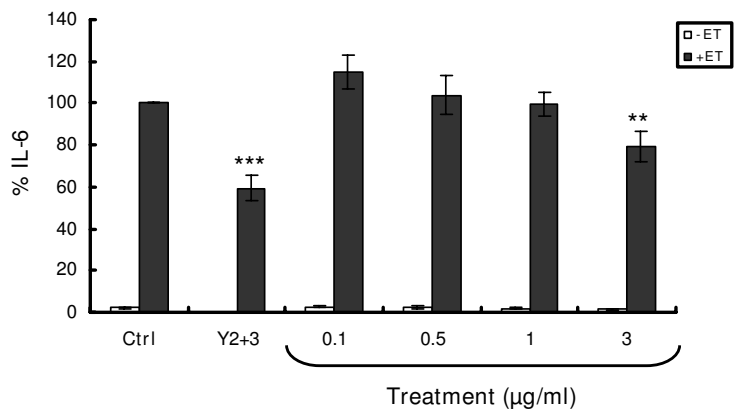

long-term exposure to $\mathrm{Y}_{2+3}$ generated an IL-6 inhibitory profile similar to that of I.2 without causing cytotoxicity, but at relatively lower concentrations, indicating that the inhibitory effect noted in I.2 was possibly due to $\mathrm{Y}_{2+3}$.

Numerous reports have shown the occurrence of FAs in members of the Ranunculaceae family [29-31]. Chemical investigation demonstrated the presence of palmitic acid, C18:2 and C18:1 isomers and stearic acid (1:5:8:1 ratio) in $\mathrm{Y}_{2+3}$. In a similar study, these FAs, along with others, were reported to exist in Ranunculus ternatus [30], a Chinese medicinal plant used as an analgesic for headache and toothache and for treating congestion, corneal pterygium and malaria.

The comparison between the anti-inflammatory activity of $\mathrm{Y}_{2+3}$ and other commonly known biologically active FAs suggested that the higher potency of $\mathrm{Y}_{2+3}$ was not due to its presumed FAs, i.e. palmitic and stearic acid and at least not the two most common isomers of C18:2 and

B

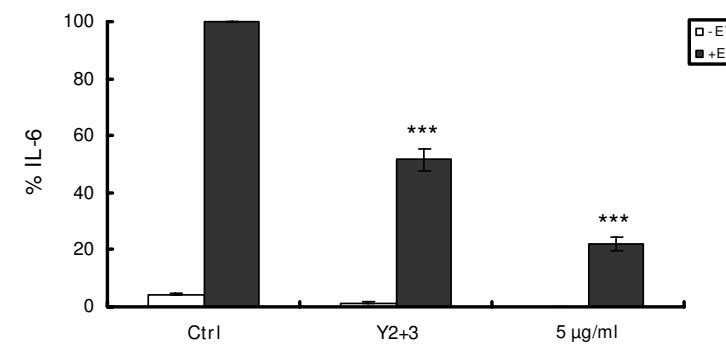

D

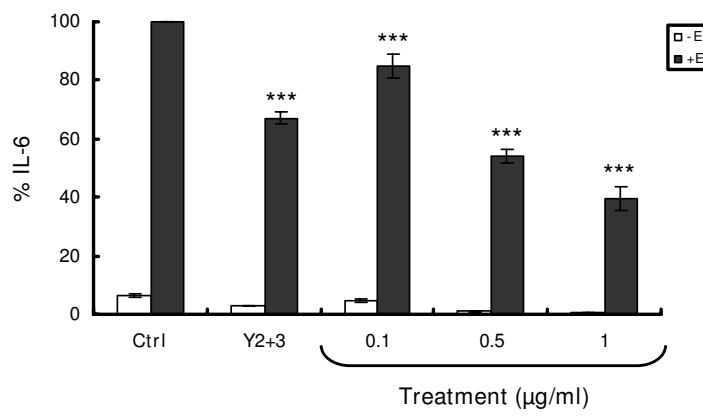

Figure 5

Exposure of SCp2 cells to $\mathbf{Y}_{2+3}$ reduces ET-induced IL-6 levels more potently than fish oil and CLA. SCp2 cells were treated (A and $\mathbf{C}$ ) on day 3 of culture 30 min before ET (short-term exposure) or (B and D) for 3 days (long-term exposure), as of day I of culture, with $\mathrm{EtOH}(\mathrm{Ctrl}), \mathrm{Y}_{2+3^{\mathrm{a}}}$, fish oil (A and B) or CLA ${ }^{\mathrm{b}}$ (C and D) at different concentrations. Cells were treated on day 3 with ET at $10 \mu \mathrm{g} / \mathrm{ml}$ in DM supplemented with I\% FBS and their media collected $9 \mathrm{hr}$ post-ET. The values depicted are the means $( \pm$ S.D.) of a triplicate treatment. Statistical significance of the difference from Ctrl+ET is with $* * P<0.01$ or $* * * P<0.00 I$. (Ctrl, control; ET, endotoxin; IL-6, interleukin-6). ${ }^{a}$ Cells were treated with $Y_{2+3}$ at 5 or $10 \mu g / m l$ for long- (B and $\mathbf{D})$ and short-term ( $\boldsymbol{A}$ and $\mathbf{C}$ ) exposure, respectively. bShort- and long-term exposures to CLA at 5 and $3 \mu \mathrm{g} / \mathrm{ml}$, respectively, were cytotoxic to cells. -ET (white square); +ET (black square). 
C18:1: linoleic and oleic acid, respectively. Even when tested at concentrations exceeding the ones normally present in $\mathrm{Y}_{2+3}$ mix, none of the FAs reduced ET-induced IL- 6 levels. Furthermore, the synthetic FA mix, containing these FAs in the same ratio as in $\mathrm{Y}_{2+3}$, did not reduce IL- 6 levels in SCp2 cells. $\mathrm{Y}_{2+3}$ has demonstrated comparable anti-inflammatory effects in IL-1-stimulated mouse intestinal epithelial Mode-K cells. $\mathrm{Y}_{2+3}$ effectively downregulated COX-2 expression in these cells, an activity not noted in its synthetic FA mix. Nevertheless, the above observations do not exclude potential combinatorial effects for these FAs. This suggestion is supported by a study that demonstrated antifertility activities in Azadirachta indica seed extract and in one of its fractions (containing palmitate, linoleate, oleate and stearate, in addition to methyl palmitate and methyl oleate), which were reduced upon further fractionation. In the same study, regrouping the obtained subfractions to reconstitute the original mixture in a similar proportion did not regenerate the original biological activity [32]. This was attributed to the synergism of the constituents of the mixture as they existed in the seed. Although this could be the

A

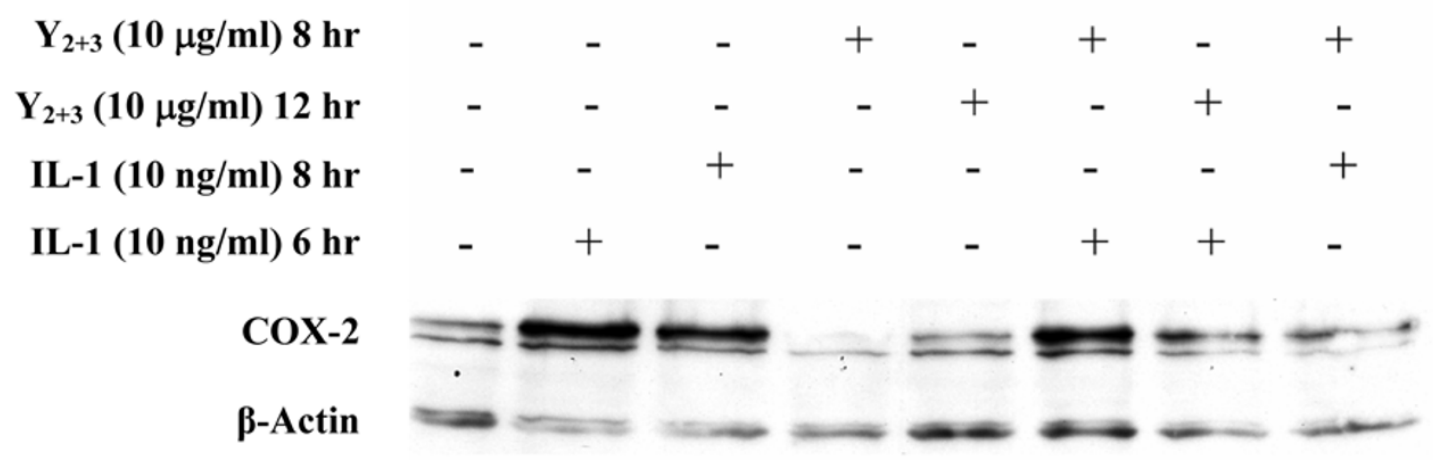

B
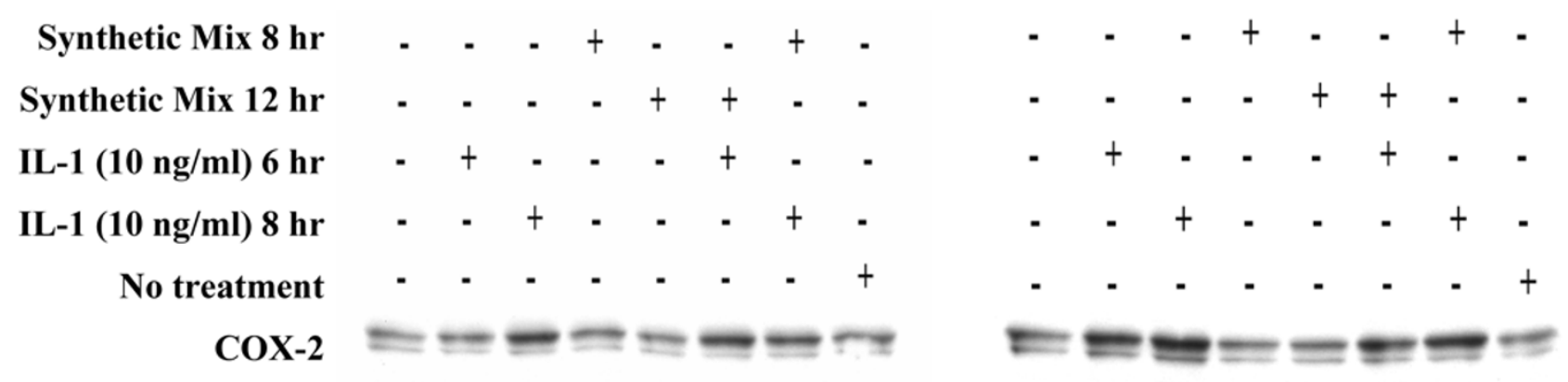

GAPDH

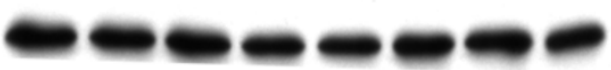

Figure 6

Exposure of Mode-K cells to $\mathbf{Y}_{2+3}$, but not to a synthetic FA mix, reduces IL-I-induced COX-2 protein levels. Mode-K cells were treated on day 2 of culture 8 or 12 hr before IL-I (pretreatment) or on day 3 (cotreatment) with (A) $Y_{2+3}$ at $10 \mu \mathrm{g} / \mathrm{ml}$ or (B) a synthetic FA mix at different concentrations (Left: $10 \mu \mathrm{g} / \mathrm{ml}$; Right: $60 \mu \mathrm{g} / \mathrm{ml}$ ) in FBS-free medium. Cells were treated on day 3 with IL-I at $10 \mathrm{ng} / \mathrm{ml}$ in the absence of FBS and their proteins extracted 6 or $8 \mathrm{hr}$ post-IL-I for western blot analysis. $\beta$-actin or GAPDH was used to demonstrate equal loading. (COX-2, cyclooxygenase-2; IL-I, interleukin-I). 
case in our study, however, our results can be explained also by possible occurrence of CLA and/or its precursor vaccenic acid as the C18:2 and C18:1 isomers, respectively. Knowing that the anti-inflammatory role of CLA, unlike oleate, palmitate and stearate, was highlighted by different studies $[9,14]$, we opted to investigate the effect of CLA on IL-6 production by SCp2 cells.

In addition, various reports demonstrated the efficacy of CLA, EPA and DHA in reversing inflammation [2,33-36]. Our comparative studies denote similar or more potent effects for $\mathrm{Y}_{2+3}$ in SCp2 cell culture model that could be noticed within a shorter exposure time or with less cytotoxic effects. Compared to fish oil, $\mathrm{Y}_{2+3}$ was able to reduce IL-6 levels within a shorter period of time; however, at longer exposures, fish oil was more potent than $\mathrm{Y}_{2+3}$. Similarly, CLA was less effective than $\mathrm{Y}_{2+3}$, even at the maximum noncytotoxic concentration for short durations, but exhibited more potent effect after long-term exposure. This suggests the presence of biologically active CLA isomer(s) in $\mathrm{Y}_{2+3}$ that could be synergized by the other FA constituents of $\mathrm{Y}_{2+3}$. Worth noting is the presence of a marketable formula of CLA that contains, in addition, palmitic, linoleic, oleic and stearic acid (Tonalin CLA, WeightLossGuide, Sarasota, FL, USA).

Studies have confirmed that dietary PUFA supplementation is capable of ameliorating IBD $[37,38]$. For instance, using a pig model of dextran sodium sulfate (DSS)induced colitis, both $n$-3 PUFA- and CLA-rich diets were shown to exert anti-inflammatory effects [39]. In a related preliminary study, $\mathrm{Y}_{2+3}$ synergized the anti-inflammatory activities in salograviolide A (SA), a sesquiterpene lactone purified from Centaurea ainetensis $[24,40]$, whereby intraperitoneal (i.p.) administration of $\mathrm{Y}_{2+3}: \mathrm{SA}$ mix reduced pro-inflammatory cytokine levels in colons of iodoacetamide-induced ulcerative colitis (UC) rats (Data not shown).

\section{Conclusion}

$\mathrm{Y}_{2+3}$, the naturally occurring FA combination derived from R. constantinopolitanus, reduces ET-induced IL-6 levels and IL-1-induced COX-2 expression in-vitro more efficiently than the highly reputable CLA and fish oil and within a shorter period of time. Our preliminary studies demonstrate similar effects for $\mathrm{Y}_{2+3}$ in an in-vivo model of IBD, making it a promising plant-derived anti-inflammatory FA mix. The mechanism of action of this mixture and the nature of its C18:1 and C18:2 isomers have not been fully elucidated. Finally, a better understanding of the specific cellular targets of $\mathrm{Y}_{2+3}$ could prove invaluable in determining the role played by FAs in inflammation prevention and resolution.

\section{Competing interests}

The authors declare that they have no competing interests.

\section{Authors' contributions}

NAS, RAE and RGS carried out the isolation and identification of plant extracts. RST, FRH, SFF and JAA performed in-vitro studies on SCp2 (RST and SFF) and Mode-K cells (FRH and JAA) and outlined mechanisms of action. RST, FRH and NAS were the primary investigators who designed the experiments. SFF carried out the statistical analysis and prepared the manuscript. All authors read and approved the final manuscript.

\section{Acknowledgements}

This work was supported by grants from HITECH, FZE, Dubai, UAE, and the research was conducted at the "Nature Conservation Center for Sustainable Futures (IBSAR)" at the American University of Beirut, Beirut, Lebanon.

\section{References}

I. Bendyk A, Marino V, Zilm PS, Howe P, Bartold PM: Effect of dietary omega-3 polyunsaturated fatty acids on experimental periodontitis in the mouse. J Periodontal Res 2009, 44:2II-2I6.

2. Changhua L, Jindong $Y$, Defa L, Lidan $Z$, Shiyan Q, Jianjun $X$ : Conjugated linoleic acid attenuates the production and gene expression of proinflammatory cytokines in weaned pigs challenged with lipopolysaccharide. I Nutr 2005, 135:239-244.

3. Du C, Fujii Y, Ito M, Harada M, Moriyama E, Shimada R, Ikemoto A, Okuyama $H$ : Dietary polyunsaturated fatty acids suppress acute hepatitis, alter gene expression and prolong survival of female Long-Evans Cinnamon rats, a model of Wilson disease. J Nutr Biochem 2004, 15:273-280.

4. Jaudszus A, Krokowski M, Möckel P, Darcan Y, Avagyan A, Matricardi $P$, Jahreis G, Hamelmann E: Cis-9,trans-I I-conjugated linoleic acid inhibits allergic sensitization and airway inflammation via a PPARgamma-related mechanism in mice. J Nutr 2008, 138:1336-1342.

5. Sadeghi S, Wallace FA, Calder PC: Dietary lipids modify the cytokine response to bacterial lipopolysaccharide in mice. Immunology 1999, 96:404-4I0.

6. Sane S, Baba M, Kusano C, Shirao K, Andoh T, Kamada T, Aikou T: Eicosapentaenoic acid reduces pulmonary edema in endotoxemic rats. J Surg Res 2000, 93:21-27.

7. Calder PC: Polyunsaturated fatty acids and inflammation. Biochem Soc Trans 2005, 33:423-427.

8. Calder PC: Polyunsaturated fatty acids, inflammatory processes and inflammatory bowel diseases. Mol Nutr Food Res 2008, 52:885-897.

9. O'Shea M, Bassaganya-Riera J, Mohede IC: Immunomodulatory properties of conjugated linoleic acid. Am J Clin Nutr 2004, 79(Suppl 6): I199-1206.

10. Zainal Z, Longman AJ, Hurst S, Duggan K, Caterson B, Hughes CE, Harwood JL: Relative efficacies of omega-3 polyunsaturated fatty acids in reducing expression of key proteins in a model system for studying osteoarthritis. Osteoarthr Cartilage 2009, I7:882-89|.

II. Gil A: Polyunsaturated fatty acids and inflammatory diseases. Biomed Pharmacother 2002, 56:388-396.

12. Nies LK, Cymbala AA, Kasten SL, Lamprecht DG, Olson KL: Complementary and alternative therapies for the management of dyslipidemia. Ann Pharmacother 2006, 40:1984-1992.

13. Pariza MW, Park Y, Cook ME: The biologically active isomers of conjugated linoleic acid. Prog Lipid Res 200I, 40:283-298.

14. Zulet MA, Marti A, Parra MD, Martinez JA: Inflammation and conjugated linoleic acid: mechanisms of action and implications for human health. J Physiol Biochem 2005, 61:483-494. 
15. Barbour EK, Al Sharif M, Sagherian VK, Habre AN, Talhouk RS, Talhouk SN: Screening of selected indigenous plants of Lebanon for antimicrobial activity. J Ethnopharmacol 2004, 93: I-7.

16. Cao BJ, Meng QY, Ji N: Analgesic and anti-inflammatory effects of Ranunculus japonicus extract. Planta Med 1992, 58:496-498.

17. Li H, Zhou C, Pan Y, Gao X, Wu X, Bai H, Zhou L, Chen Z, Zhang S, Shi S, Luo J, Xu J, Chen L, Zheng X, Zhao Y: Evaluation of antiviral activity of compounds isolated from Ranunculus sieboldii and Ranunculus sceleratus. Planta Med 2005, 71: | | 28-1 | 33.

18. Mares D: Antimicrobial activity of protoanemonin, a lactone from ranunculaceous plants. Mycopathologia 1987, 98: I33-140.

19. Prieto JM, Recio MC, Giner RM, Máñez S, Ríos JL: Pharmacological approach to the pro- and anti-inflammatory effects of Ranunculus sceleratus L. J Ethnopharmacol 2003, 89: I3|-137.

20. Schinella GR, Tournier HA, Prieto JM, Rios JL, Buschiazzo H, Zaidenberg A: Inhibition of Trypanosoma cruzi growth by medical plant extracts. Fitoterapia 2002, 73:569-575.

21. Duan H, Zhang Y, Xu J, Qiao J, Suo Z, Hu G, Mu X: Effect of anemonin on NO, ET-I and ICAM-I production in rat intestinal microvascular endothelial cells. I Ethnopharmacol 2006, 104:362-366.

22. Lee TH, Huang NK, Lai TC, Yang AT, Wang GJ: Anemonin, from Clematis crassifolia, potent and selective inducible nitric oxide synthase inhibitor. J Ethnopharmacol 2008, I I6:5 I 8-527.

23. Martin ML, Ortíz de Urbina AV, Montero MJ, Carrón R, San Román $\mathrm{L}$ : Pharmacologic effects of lactones isolated from Pulsatilla alpina subsp. apiifolia. J Ethnopharmacol |988, 24:|85-|9|.

24. Saliba NA, Dakdouki S, Homeidan F, Kogan J, Bouhadir K, Talhouk S, Talhouk R: Bio-guided identification of an anti-inflammatory guaianolide from Centaurea ainetensis. Pharm Biol 2009, 47:70I-707.

25. Homaidan FR, Chakroun I, El-Sabban ME: Regulation of nuclear factor-kappaB in intestinal epithelial cells in a cell model of inflammation. Mediators Inflamm 2003, 1 2:277-283.

26. Safieh-Garabedian B, Mouneimne GM, El-Jouni W, Khattar M, Talhouk R: The effect of endotoxin on functional parameters of mammary CID-9 cells. Reproduction 2004, I 27:397-406.

27. Talhouk RS, Karam C, Fostok S, El-Jouni W, Barbour EK: Antiinflammatory bioactivities in plant extracts. J Med Food 2007, 10:1-10.

28. Gabay C: Interleukin-6 and chronic inflammation. Arthritis Res Ther 2006, 8(Suppl 2):3.

29. Aitzetmuller K: An unusual fatty acid pattern in Eranthis seed oil. Lipids 1996, 31:20I-205.

30. Chen ], Yao C, Xia LM, Ouyang PK: [Determination of fatty acids and organic acids in Ranunculus ternatus Thunb using GCMS]. Guang Pu Xue Yu Guang Pu Fen Xi 2006, 26: I 550-I552.

31. Spencer GF, Kleiman R, Earle FR, Wolff IA: Unusual olefinic fatty acids in seed oils from two genera in the Ranunculaceae. Lipids 1970, 5:277-278.

32. Garg S, Talwar GP, Upadhyay SN: Immunocontraceptive activity guided fractionation and characterization of active constituents of neem (Azadirachta indica) seed extracts. J Ethnopharmacol 1998, 60:235-246.

33. Lo CJ, Chiu KC, Fu M, Lo R, Helton S: Fish oil decreases macrophage tumor necrosis factor gene transcription by altering the NF kappa B activity. J Surg Res 1999, 82:216-221.

34. Puglia C, Tropea S, Rizza L, Santagati NA, Bonina F: In vitro percutaneous absorption studies and in vivo evaluation of antiinflammatory activity of essential fatty acids (EFA) from fish oil extracts. Int J Pharm 2005, 299:4I-48.

35. Shen CL, Dunn DM, Henry JH, Li Y, Watkins BA: Decreased production of inflammatory mediators in human osteoarthritic chondrocytes by conjugated linoleic acids. Lipids 2004, 39:161-166

36. Tappia PS, Grimble RF: Complex modulation of cytokine induction by endotoxin and tumour necrosis factor from peritoneal macrophages of rats by diets containing fats of different saturated, monounsaturated and polyunsaturated fatty acid composition. Clin Sci (Lond) 1994, 87: I73-178.

37. Belluzzi A: Polyunsaturated fatty acids (n-3 PUFAs) and inflammatory bowel disease (IBD): pathogenesis and treatment. Eur Rev Med Pharmacol Sci 2004, 8:225-229.

38. Wild GE, Drozdowski L, Tartaglia C, Clandinin MT, Thomson AB: Nutritional modulation of the inflammatory response in inflammatory bowel disease--from the molecular to the integrative to the clinical. World J Gastroenterol 2007, I3:I-7.

39. Bassaganya-Riera J, Hontecillas R: CLA and n-3 PUFA differentially modulate clinical activity and colonic PPAR-responsive gene expression in a pig model of experimental IBD. Clin Nutr 2006, 25:454-465.

40. Al-Saghir J, Al-Ashi R, Salloum R, Saliba NA, Talhouk RS, Homaidan FR: Anti-inflammatory properties of Salograviolide A purified from Lebanese plant Centaurea ainetensis. BMC Complement Altern Med 9:36.

4I. Post GE: The plants. In Flora of Syria, Palestine and Sinai Volume I. 2nd edition. Edited by: Dinsmore JE. Beirut: American Press; 1932: 14.

\section{Pre-publication history}

The pre-publication history for this paper can be accessed here:

http://www.biomedcentral.com/1472-6882/9/44/prepub
Publish with Biomed Central and every scientist can read your work free of charge

"BioMed Central will be the most significant development for disseminating the results of biomedical research in our lifetime. "

Sir Paul Nurse, Cancer Research UK

Your research papers will be:

- available free of charge to the entire biomedical community

- peer reviewed and published immediately upon acceptance

- cited in PubMed and archived on PubMed Central

- yours - you keep the copyright 